\title{
PENGARUH MUTASI PEGAWAI TERHADAP MOTIVASI KERJA APARATUR SIPIL NEGARA DI KANTOR BADAN KEPEGAWAIAN DAERAH (BKD) KABUPATEN NIAS BARAT
}

\author{
Darma Manalu \\ Fakultas Ilmu Sosial Dan Ilmu Politik, Universitas HKBP Nommensen \\ darmamanalu64@gmail.com
}

\begin{abstract}
ABSTRAK : Aparatur Sipil Negara (ASN) yang merupakan Aparatur Negara yang menyeleng-garakan pemerintahan dalam melaksanakan pembangunan nasional merupakan tulang punggung pemerintah. Kelancaran penyelenggaraan pemerintahan dan pelaksanaan pembangunan nasional tergantung pada kesempurnaan aparatur negara baik ditingkat pusat maupun ditingkat daerah. Dalam rangka mencapai tujuan nasional sebagaimana dikemukakan di atas, diperlukan adanya Aparatur Sipil Negara yang penuh kesediaan dan ketaatan kepada Pancasila, UndangUndang Dasar 1945, Negara dan Pemerintah serta bersatu padu, bermental baik, berwibawa, kuat berdaya guna, bersih, berkualitas tinggi dan sadar akan tanggungjawabnya sebagai unsur Aparatur Negara, abdi Negara dan abdi masyarakat. Untuk mewujudkan Aparatur Sipil Negara yang sempurna sebagaimana yang dimaksudkan diatas, maka Aparatur Sipil perlu dibina dengan sebaikbaiknya. Salah satu bentuk pembinaan terhadap Aparatur Sipil Negara adalah Mutasi sebagai penjelmaan atau perwujudan dinamika organisasi yang dijadikan sebagai salah satu cara untuk mencapai tujuan organisasi. Dalam pelaksanaan mutasi harus benar-benar berdasarkan penilaian yang objektif mengingat sistem pemberian mutasi dimaksudkan untuk memberikan peluang bagi para Aparatur Sipil Negara untuk mengembangkan potensi yang dimilikinya. Motivasi kerja para Aparatur Sipil Negara juga dapat menurun apabila pihak atasan tidak memperhatikan kepentingan para bawahan. Hal ini akan menurunkan motivasi kerja baik Aparatur Sipil Negara. Indikator dari turunnya semangat kerja antara lain: rendah nya produktivitas, tingkat absensi pegawai tinggi, dan lain-lain. Pelaksanaan mutasi kerja dengan baik dan sesuai dengan peraturan yang berlaku maka mutasi tersebut akan berdampak positif terhadap pegawai seperti meningkatkan semangat kerja. Namun bila mutasi tersebut dilakukan tanpa memperhatikan dengan seksama dan tanpa dilandasi dengan argumentasi yang meyakinkan maka mutasi akan berdampak negatif terhadap pegawai dan organisasi tersebut.
\end{abstract}

Kata Kunci: Mutasi, motivasi kerja, ,Aparatur Sipil Negara (ASN)

\begin{abstract}
The State Civil Apparatus (ASN), which is the State Apparatus that organizes the government in carrying out national development, is the backbone of the government. The smooth running of government and the implementation of national development depends on the perfection of the state apparatus both at the central and regional levels. In order to achieve the national goals as stated above, it is necessary to have a State Civil Apparatus who is full of willingness and obedience to Pancasila, the 1945 Constitution, the State and the Government and is united, has good mentality, is authoritative, strong, efficient, clean, of high quality and aware of their responsibilities as elements of the State Apparatus, State servants and public servants. To realize the perfect State Civil Apparatus as intended above, the Civil Apparatus needs to be fostered as well as possible. One form of fostering the State Civil Apparatus is Mutation as an incarnation or embodiment of organizational dynamics which is used as a way to achieve organizational goals. In the implementation of mutations, it must be based on an objective assessment considering that the transfer system is intended to provide opportunities for State Civil Apparatus to develop their potential. The work motivation of the State Civil Apparatus can also decrease if the superiors do not pay attention to the interests of their subordinates. This will reduce the work motivation of both the State Civil Apparatus. Indicators of declining morale include: low productivity, high employee absenteeism, and others. Thus, it will certainly affect the work motivation of employees in an organization. Mutation will have a positive impact on employees, such as increasing work morale. However, if the mutation is carried out without
\end{abstract}


paying close attention and without being based on convincing arguments, the mutation will have a negative impact on the employee and the organization.

Keywords: Mutation, work motivation, State Civil Apparatus (ASN)

Peranan sumber daya manusia merupakan salah satu faktor utama yang sangat penting dalam suatu organisasi. Pemanfaatan sumber daya manusia secara efektif merupakan jalan bagi suatu organisasi untuk mempertahankan kelangsungan hidup dan pertumbuhan di masa yang akan datang. Dengan kata lain, keberhasilan atau kemunduran suatu organisasi tergantung pada keahlian dan keterampilan pegawainya masing-masing yang bekerja di dalamnya.

Pembangunan pada hakekatnya adalah kesadaran untuk melakukan kegiatan memperbaiki, mendirikan bahkan menumbuhkan serta meningkatkan daya upaya yang mengarah kepada keadaan yang lebih baik dengan dilandasi oleh motivasi, kemauan dan tekad yang tinggi yang bertujuan untuk melakukan kegiatankegiatan yang bersifat memperbaiki dan meningkatkan kesejahteraan rakyat Indonesia pada umumnya. Tujuan tersebut baru dapat dicapai apabila pembangunan nasional dilaksanakan secara menyeluruh dengan pemanfaatan sumber daya manusia dan sumber daya bukan manusia, serta pelaksanaan pembangunan disegala bidang, terencana, terarah, bertahap dan berkesinambungan. Salah satu bidang tersebut adalah pembangunan manusia seutuhnya. Dalam hal ini keberhasilan pembangunan tergantung pada aspek manusianya yakni sebagai pemimpin, pelaksana dan pengelola sumber daya yang ada dalam negara, yang dalam hal ini adalah Aparatur Sipil Negara (ASN).

ASN merupakan aparatur negara yang menyelenggarakan pemerintahan dalam melaksanakan pembangunan nasional merupakan tulang punggung pemerintah. Kelancaran penyelenggaraan pemerintahan dan pelaksanaan pembangunan nasional tergantung pada kesempurnaan ASN baik ditingkat pusat maupun ditingkat daerah. Dalam rangka mencapai tujuan nasional sebagaimana dikemukakan di atas, diperlukan adanya ASN yang penuh kesediaan dan ketaatan kepada Pancasila, Undang-Undang Dasar 1945, negara dan pemerintah serta persatu padu, bermental baik, berwibawa, kuat berdaya guna, bersih, berkualitas tinggi dan sadar akan tanggungjawabnya sebagai unsur aparatur Negara, abdi Negara dan abdi masyarakat.

Dengan adanya undang-undang Republik Indonesia Nomor 5 Tahun 2014 tentang ASN, dan Peraturan Pemerintah Republik Indonesia Nomor 9 tahun 2003 tentang Wewenang Pengangkatan, Pemindahan, dan Pemberhentian Pegawai Negeri Sipil. Kedua Peraturan perundang-undangan tersebut merupakan pedoman pelaksanaan mutasi kepegawaian di setiap instansi pemerintah umum dan daerah. Menurut undang-undang Republik Indonesia Nomor 5 Tahun 2014, bahwa yang termasuk ASN adalah mereka yang setelah memenuhi syarat-syarat yang ditentukan dalam peraturan perundang-undangan yang berlaku, diangkat oleh pejabat yang berwenang dan diserahi tugas Negara lainnya yang ditetapkan 
berdasarkan satu peraturan perundang-undangan dan digaji menurut peraturan perundang-undangan yang berlaku.

Dengan tujuan pembinaan tersebut diharapkan bahwa setiap pegawai yang ada dalam organisasi yang bersangkutan dapat memberikan prestasi kerja yang sebaik-baiknya. Sehingga benar-benar dapat berfungsi sebagai penghasil kerja yang tepat guna dan berhasil sesuai dengan sasaran organisasi yang hendak dicapai. Salah satu bentuk pembinaan terhadap ASN adalah mutasi sebagai penjelmaan atau perwujudan dinamika organisasi yang dijadikan sebagai salah satu cara untuk mencapai tujuan organisasi.

Dari kutipan di atas terlihat bahwa mutasi tidak terlepas dari upaya pemenuhan kebutuhan tenaga kerja yang sangat berperan dalam meningkatkan motivasi kerja pegawai, dimana dalam kegiatan pelaksanaan mutasi kerja sering disalahtafsirkan oleh orang yaitu sebagai hukuman jabatan atau di dasarkan atas hubungan baik antara atasan dan bawahan. Dalam pelaksanaan mutasi harus benar-benar berdasarkan penilaian yang objektif mengingat sistem pemberian mutasi dimaksudkan untuk memberikan peluang bagi para ASN untuk mengembangkan potensi yang dimilikinya.

Motivasi kerja para ASN juga dapat menurun apabila pihak atasan tidak memperhatikan kepentingan para bawahan. Hal ini akan menurunkan motivasi kerja baik ASN. Indikator dari turunnya motivasi kerja antara lain: rendahnya produktivitas, tingkat absensi pegawai tinggi, dan lain-lain. Dengan demikian pastilah akan mempengaruhi motivasi kerja pegawai dalam suatu organisasi.

Hal inilah yang mendorong peneliti untuk meneliti masalah Mutasi yang dikaitkan dengan Motivasi kerja Aparatur Sipil Negara dengan pemikiran bagaimana upaya untuk menumbuhkan Motivasi kerja di kalangan Aparatur Sipil Negara sehingga Motivasi kerja pegawai dapat meningkat, khususnya untuk ASN pada kantor Badan Kepegawaian Daerah Kabupaten Nias Barat.

Dari latar belakang di atas maka yang menjadi perumusan masalah dalam penelitian ini adalah: "Apakah ada pengaruh mutasi terhadap motivasi kerja Aparatur Sipil Negara di Kantor Badan Kepegawaian Daerah Kabupaten Nias Barat?". Penelitian bertujuan untuk mengetahui apakah ada pengaruh mutasi terhadap peningkatan motivasi kerja ASN di Badan Kepegawaian Daerah (BKD) Kabupaten Nias Barat.

Dalam dunia ketenagakerjaan, aktivitas pemindahan tenaga kerja dari satu bagian ke bagian lain bukanlah merupakan kegiatan yang dianggap rahasia. Kegiatan ini dilakukan oleh manajemen sumber daya manusia untuk megembangkan kualitas kinerja (pegawai) yang menjadi tanggungjawabnya.

Tenaga kerja dimutasikan berarti mereka diberikan kesempatan untuk meningkatan dan mengembangkan kualitas dan kuantitas kerjanya, sekaligus mengembangkan karier dirinya untuk lebih maju. Kegiatan mutasi juga dapat menghilangkan rasa jenuh dalam melaksanakan tugas dari pekerjaan yang itu-itu saja dan beralih pada kondisi kerja yang baru. Selain itu, mutasi terjadi karena tenaga kerja kurang mampu melaksanakan tugas dan pekerjaannya. 
Sadili Samsudin, (2010.254) Mutasi adalah kegiatan yang berhubungan dengan proses pemindahan fungsi, tanggungjawab, dan status ketenagakerjaan pegawai kesituasi tertentu dengan tujuan agar tenaga kerja yang bersangkutan memperoleh kepuasan kerja yang mendalam dan dapat memberikan prestasi dan kontribusi kerja yang maksimal pada perusahaan. Malayu S.P. Hasibuan (2016. 102) menyatakan bahwa mutasi adalah suatu perubahan posisi, jabatan, tempat, pekerjaan yang dilakukan baik secara horizontal maupun vertikal di dalam satu organisasi. Selanjutnya Sondang P. Siagian (2013. 171) menyatakan bahwa ada dua bentuk Alih Tugas atau Mutasi. Bentuk pertama adalah penempatan seseorang pada tugas baru dengan tanggungjawab, hierarki jabatan dan penghasilan yang relatif sama dengan statusnya yang lama. Bentuk kedua adalah alih tempat.

Pada dasarnya mutasi termasuk dalam fungsi pengembangan karyawan, karena tujuannya untuk meningkatkan efisiensi dan efektivitas kerja dalam pemerintahan tersebut. Jadi, dapat disimpulkan bahwa mutasi diartikan sebagai perubahan mengenai atau pemindahan kerja/ jabatan lain dengan harapan pada jabatan baru itu pegawai lebih berkembang. Kedua peraturan tersebut di atas merupakan pedoman pelaksanaan mutasi kepegawaian di setiap instansi pemerintah umum dan daerah yang telah ditetapkan berdasarkan peraturan Perundang-Undangan Republik Indonesia dan peraturan Pemerintah Republik Indonesia.

Pelaksanaan mutasi pegawai mempunyai banyak manfaat dan tujuan yang sangat berpengaruh kepada kemampuan dan kemauan kerja pegawai yang mengakibatkan suatu keuntungan bagi perusahaan itu sendiri. Mutasi pegawai ini merupakan salah satu metode dalam program pengembangan manajemen yang berfungsi untuk meningkatkan efektivitas manajer secara keseluruhan dalam pekerjaan dan jabatannya dengan memperluas pengalaman dan membiasakan dengan berbagai aspek dari operasi instansi ataupun perusahaan. Melalui alih tugas atau mutasi para karyawan sesungguhnya memperoleh manfaat yang tidak sedikit, antara lain dalam bentuk: 1) Pengalaman baru; 2) Cakrawala pandangan yang lebih luas; 3 )Tidak terjadinya kebosanan atau kejenuhan; 4) Perolehan pengetahuan dan keterampilan baru; 5) Perolehan prospektif baru mengenai kehidupan organisasional; 6) Persiapan untuk menghadapi tugas baru, misalnya karena promosi; 7) Motivasi dan keputusan kerja yang lebih tinggi berkat tantangan dan situasi baru yang dihadapi. Sondang P. Siagian (2013. 178). Mutasi juga dapat menurunkan kegairahan kerja karena dianggap sebagai hukuman dan memperburuk produktivitas kerja karena adanya ketidaksesuaian dan ketidakmampuan kerja karyawan. Bila terjadi keadaan yang demikian maka mutasi tidak mencapai tujuan yang diharapkan, yaitu bertambahnya efektivitas dan efesiensi dalam perkerjaan.

Setiap organisasi selalu mengharapkan agar produktivitas kerja para pegawainya dapat terus meningkat. Namun dalam kenyataannya, yang mendukung untuk mencapai tujuan tersebut sering kurang mendapat perhatian, tidak adanya usaha-usaha yang dilakukan untuk meningkatkan semangat kerja dan 
kegairahan bekerja para pegawai. Memang dapat diakui, bahwa para pegawai dapat bekerja dengan cara diawasi atau dengan cara paksaan/ancaman, tetapi akan berbeda halnya jika para pegawai bekerja dengan kemauannya sendiri atau dengan semangat kerja yang baik.

Motivasi adalah pekerjaan yang dilakukan manajer dalam memberikan inspirasi, semangat, dan dorongan kepada orang lain, dalam hal ini karyawannya, untuk mengambil tindakan-tindakan tertentu. Liang Gie, Sadili Samsudin (2005. 281). Motivasi pada hakekatnya adalah proses memengaruhi atau mendorong dari luar terhadap seseorang atau kelompok kerja agar mereka mau melaksanakan sesuatu yang ditetapkan. Sadili Samsudin, (2005. 281)

Sehingga dapat disimpulkan bahwa motivasi kerja adalah sesuatu yang menimbulkan dorongan atau semangat kerja. Jadi apabila suatu organisasi mampu meningkatkan semangat dan kegairahan kerja, maka organisasi akan memperoleh banyak keuntungan.

Tujuan dan manfaat Motivasi Kerja adalah dengan meningkatnya semangat dan kegairahan kerja, maka pekerjaan akan lebih cepat diselesaikan,kerusakan akan dapat dikurangi, absensi akan dapat diperkecil. Alex S. Nitisemo (2015. 160). Sehingga instansi atau organisasi perlu menimbulkan motivasi kerja pegawai yang tinggi, akan mempermudah untuk mencapai tujuan organisasi yang telah ditetapkan sebelumnya, sementara apabila motivasi kerja rendah maka produktivitas juga rendah. Indikasi turunnya motivasi kerja antara lain:

1. Turun/rendahnya produktivitas;

2. Tingkat absensi yang naik/tinggi;

3. Labour turnover, tingkat perpindahan (buruh/pegawai) yang tinggi;

4. Tingkat kerusakan yang naik/tinggi;

5. Kegelisahan di mana-mana;

6. Tuntutan yang seringkali terjadi;

7. Pemogokan.

Dari uraian diatas, dengan memperhatikan tujuan dan manfaat dari motivasi kerja, serta dengan mengetahui faktor-faktor yang mempengaruhi rendahnya motivasi kerja dan indikasi yang ditimbulkan maka perlu diadakan peningkatan kerja.

Salah satu tujuan pelaksanaan mutasi pegawai adalah untuk mengusahakan orang tepat pada tempat yang tepat "the right man on the right place". Dengan demikian akan dapat meningkatkan motivasi kerja pegawai.

Hubungan mutasi kerja dengan motivasi kerja adalah dengan jalan memutasikan kerja, maka selain semangat dan kegairahan kerja dapat timbul kembali, maka pekerjaan yang baru itu punakan sesuai dengan kemampuan dan kesenangannya. Alex S. Nitisemo (2015. 122). Mutasi sangat berpengaruh dengan motivasi kerja seseorang pegawai, karena tempat dan posisi yang baru dapat membuat seseorang lebih bersemangat lagi dalam menjalankan pekerjaannya. Situasi kerja yang baru dapat membuat seseorang lebih giat lagi dan menunjukkan prestasi kerjanya untuk mendapatkan sesuatu yang lebih baik lagi. Motivasi kerja seseorang dapat menurun apabila seorang pegawai merasa bosan dengan pekerjaannya sekarang ini, jadi perlu dilakukan mutasi untuk membuat motivasi kerja nya menjadi lebih baik lagi. 
Menurut Siswanto Sastrohadiwiryo, mutasi adalah kegiatan ketenagakerjaan yang berhubungan dengan proses pemindahan fungsi, tanggungjawab, dan status ketenagakerjaan tenaga kerja kesituasi tertentu dengan tujuan agar tenaga kerja yang bersangkutan memperoleh kepuasan kerja yang mendalam dan dapat memberikan prestasi kerja yang semaksimal mungkin kepada perusahaan. Siswanto Sastrohadiwiryo, (2003. 246).

Mutasi tidak terlepas dari upaya pemenuhan kebutuhan tenaga kerja, juga sangat berperan dalam meningkatkan motivasi dan semangat kerja pegawai, dimana dalam kegiatan pelaksanaan mutasi kerja sering disalahtafsirkan oleh orang yaitu sebagai hukuman jabatan atau di dasarkan atas hubungan baik antara atasan dan bawahan. Apabila pelaksanaan mutasi pegawai dengan baik dan sesuai dengan peraturan yang berlaku maka mutasi tersebut akan berdampak positif terhadap pegawai seperti meningkatkan motivasi kerja. Namun bila mutasi tersebut dilakukan tanpa memperhatikan dengan seksama dan tanpa dilandasi dengan argumentasi yang meyakinkan maka mutasi akan berdampak negatif terhadap pegawai dan organisasi tersebut.

Hipotesis merupakan jawaban sementara terhadap rumusan masalah penelitian, dimana rumusan masalah penelitian telah dinyatakan dalam bentuk kalimat pertanyaan. Sugiyono, (2014. 99). Hipotesis juga dapat dinyatakan sebagai jawaban teoritis terhadap rumusan masalah penelitian, belum jawaban yang empirik. Berdasarkan permasalahan tersebut, peneliti mengajukan hipotesis sebagai berikut "Terdapat Pengaruh Mutasi terhadap Motivasi Kerja Aparatur Sipil Negara (ASN) di Kantor Badan Kepegawaian Daerah Kabupaten Nias Barat.

Defenisi Operasional dimaknai sebagai sebuah petunjuk yang menjelaskan kepada peneliti mengenai bagaimana mengukur sebuah variabel secara konkret.

Nanang Martono,(2015. 67). Defenisi operasional dalam penelitian ini adalah: Mutasi adalah segala sesuatu perubahan mengenai seseorang pegawai seperti pengangkatan, pemindahan, pemberhentian, pemensiunan, pemerintahan susunan keluarga, dan lain-lain. Namun mengingat banyaknya jenis mutasi pegawai, maka dalam hal ini dibatasi hanya mengenai mutasi dalam hal perubahan jabatan kerja saja. Indikatornya sebagai berikut :

a. Frekwensi mutasi

Frekwensi mutasi adalah tingkat keseringan pelaksanaan mutasi atau pemindahan jabatan dalam organisasi.

b. Alasan mutasi

Alasan mutasi adalah alasan-alasan atau motivasi yang mendorong dilaksanakannya perpindahan atau mutasi tersebut. Ketetapan dalam melaksanakan mutasi yang disesuaikan dengan:

1. Kemampuan kerja pegawai.

2. Tingkat pendidikan.

3. Lamanya masa jabatan.

4. Tanggung jawab atau beban kerja.

5. Kesenangan atau keinginan.

6. Kebijaksanaan atau peraturan yang berlaku.

7. Kesesuaian antara jabatan yang lama dan jabatan yang baru.

Motivasi kerja adalah kesediaan seorang pegawai atau kemauan aparatur pemerintah untuk melaksanakan pekerjaan secara giat dan konsekwen sesuai dengan kedudukan dan fungsinya di dalam organisasi demi mencapai tujuan bersama yang telah ditetapkan.Indikatornya sebagai berikut: 
a. Produktivitas Kerja

Produktivitas Kerja adalah hasil dari suatu pekerjaan yang dilakukan pegawai.

b. Kepuasan terhadap tugas

Kepuasan terhadap tugas adalah kepuasan para pegawai terhadap tugas dan pekerjaannya karena memperoleh tugas yang disukainya.

c. Tingkat kehadiran

Tingkat kehadiran adalah persentase kehadiran dalam tugas setiap hari.

d. Rasa Keamanan

Rasa Keamanan adalah adanya rasa keamanan dan ketenangan jiwa, atas jaminan kepastian serta perlindungan terhadap segala sesuatu yang dapat membahayakan diri pribadi dan karir dalam pekerjaan.

e. Gaji

Gaji adalah hasil yang diterima pegawai atas hasil kerjanya.

\section{METODE PENELITIAN}

Bentuk penelitian yang dipergunakan dalam penelitian ini adalah bentuk penelitian korelasional dengan menggunakan pendekatan kuantitatif dan menggunakan rumus statistik untuk membantu menganalisa data dan fakta yang diperoleh.

Penelitian ini dilakukan di Kantor Badan Kepegawaian Daerah Kabupaten Nias Barat - Sumatera Utara pada bulan Juli 2017. Sebelum penelitian dilaksanakan, maka peneliti harus menentukan terlebih dahulu populasi yang akan diteliti. Populasi adalah wilayah generalisasi yang terdiri atas objek/subjek yang mempunyai kualitas dan karakteristik tertentu yang ditetapkan oleh peneliti untuk dipelajari dan kemudian ditarik kesimpulannya. Sugiyono (119)

Dalam penelitian ini yang menjadi populasi penelitian adalah seluruh ASN yang ada di Kantor Badan Kepegawaian Daerah Kabupaten Nias Barat mulai tahun 2015-2017. Sampel merupakan bagian populasi yang memiliki ciri-ciri atau keadaan tertentu yang akan diteliti. Nanang Martono ( 269).

Menurut Suharsimi Arikunto (2013. 173) mengatakan:"Jika jumlah populasinya kurang dari 100 orang, maka sampelnya diambil keseluruhan. Tapi jika jumlahnya lebih dari 100 orang, maka bisa diambil $10-15 \%$ atau $15-25 \%$ dari jumlah populasinya".

Berdasarkan keterangan di atas, maka sampel penelitian adalah semua ASN yang ada di Kantor Badan Kepegawaian Daerah Kabupaten Nias Barat periode 2015-2017 yang dimutasi ke dalam, keluar, dan perpindahan jabatan dalam instansi BKD berjumlah 32 orang. Data ini menyesuaikan pada data kantor BKD pegawai yang dimutasi ke luar $\mathrm{BKD}$, pegawai yang dimutasi sebagai Pegawai BKD, dan pegawai yang berpindah jabatan dalam struktur organisasi BKD periode 2015-2017 di Kabupaten Nias Barat.

Sebelum instrumen penelitian digunakan maka terlebih dahulu diadakan uji validitas dan reliabilitas. Uji validitas dilakukan untuk mengukur apakah data yang telah didapat setelah penelitan merupakan data yang valid dan alat ukur yang digunakan (kuesioner). Sugiono, (109) Uji validitas ini dilakukan kepada 28 orang pegawai Badan Kepegawaian Daerah Kabupaten Nias Barat sebagai responden diluar dari pada sampel. Metode yang digunakan adalah dengan membandingkan 
antara nilai korelasi atau $r_{\text {hitung }}$ dari variabel penelitian dengan nilai $r_{\text {tabel }}$. Pengujian validitas dan reliabilitas dalam penelitian ini menggunakan bantuan Software SPSS (Statistic Package and Social Science) 19.0 for Windows.

Kriteria dalam menentukan validitas suatu kuesioner adalah sebagai berikut:

1. Jika $r_{\text {hitung }}>r_{\text {tabel }}$ maka pertanyaan dinyatakan valid.

2. Jika $r_{\text {hitung }}<r_{\text {tabel }}$ maka pertanyaan dinyatakan tidak valid.

Uji Reliabilitas dilakukan untuk melihat apakah alat ukur yang digunakan (kuesioner) menujukkan konsistensi dalam mengukur gejala yang sama. Sugiono ( 110). Pertanyaan yang telah dinyatakan valid dalam uji validitas, maka akan ditentukan reliabilitasnya dengan kriteria sebagai berikut:

1. Jika $r_{\text {alpha }}$ positif atau $>$ dari $r_{\text {tabel }}$ maka pertanyaan reliabel.

2. Jika $r_{\text {alpha }}$ negatif atau $<$ dari $r_{\text {tabel }}$ maka pertanyaan tidak reliabel.

Penelitian ini menggunakan teknis analisis data yaitu Analisis Deskriptif. Dimana metode analisis deskriptif merupakan suatu metode analisis dimana data yang telah diperoleh, disusun, dikelompokkan, dianalisis, kemudian diinterpretasikan secara objektif sehingga diperoleh gambaran tentang masalah yang dihadapi dan menjelaskan hasil perhitungan.

Regresi Linear Sederhana adalah Metode Statistik yang berfungsi untuk menguji sejauh mana hubungan sebab akibat antara Variabel Faktor Penyebab (X) terhadap Variabel Akibatnya (Y). Faktor Penyebab pada umumnya dilambangkan dengan $\mathrm{X}$ atau disebut juga dengan Predictor sedangkan Variabel Akibat dilambangkan dengan $\mathrm{Y}$ atau disebut juga dengan Response. Regresi Linear Sederhana atau sering disingkat dengan SLR (Simple Linear Regression) juga merupakan salah satu Metode Statistik yang dipergunakan dalam produksi untuk melakukan peramalan ataupun prediksi tentang karakteristik kualitas maupun Kuantitas. Dalam penelitian ini peneliti menggunakan analisis statistik regresi linier sederhana. Persamaan yang digunakan adalah:

$$
\mathbf{Y}=\mathbf{a}+\mathbf{b X}
$$

Keterangan:

$\mathrm{Y}=$ Variabel Response atau Variabel Akibat (Dependent)

$\mathrm{X}=$ Variabel Predictor atau Variabel Faktor Penyebab (Independent)

$\mathrm{a}=$ Konstanta

$\mathrm{b}=$ Koefisien regresi (kemiringan); besaran Response yang ditimbulkan oleh Predictor.

Untuk mengetahui pengaruh kompetensi kinerja pegawai maka dilakukan pengujian dengan menggunakan pengujian parsial (Uji t). Uji t dilakukan untuk mengetahui seberapa jauh pengaruh suatu variabel independen secara parsial (individual) terhadap variasi variabel dependen.

Kriteria pengujiannya adalah:

$\mathrm{H}_{0}: \mathrm{b}_{1}=0$, artinya secara parsial tidak terdapat pengaruh yang positif dan signifikan dari variabel independen terhadap variabel dependen.

$\mathrm{H}_{\mathrm{a}}: \mathrm{b}_{1} \neq 0$, artinya secara parsial terdapat pengaruh yang positif dan signifikan dari variabel independen terhadap variabel dependen.

Kriteria pengambilan keputusan adalah

$\mathrm{H}_{0}$ diterima jika $\mathrm{t}_{\text {hitung }}<\mathrm{t}_{\text {tabel }}$ pada $\alpha=5 \%$ 
Ha ditolak jika $t_{\text {hitung }}>t_{\text {tabel }}$ pada $\alpha=5 \%$

Koefisien Determinasi $\left(\mathrm{R}^{2}\right)$ digunakan untuk mengukur seberapa besar kontribusi variabel bebas (X) terhadap variabel terikat (Y). Jika Koefisien Determinasi $\left(\mathrm{R}^{2}\right)$ semakin besar (mendekati satu) menunjukkan semakin baik kemampuan variabel $\mathrm{X}$ menerangkan variabel $\mathrm{Y}$ dimana $0<\mathrm{R}^{2}<1$. Sebaliknya, jika $\mathrm{R}^{2}$ semakin kecil (mendekati nol), maka akan dapat dikatakan bahwa pengaruh variabel bebas adalah kecil terhadap variabel terikat. Hal ini berarti model yang digunakan tidak kuat untuk menerangkan pengaruh variabel bebas yang diteliti terhadap variabel terikat.

\section{HASIL}

Wilayah Kabupaten Nias Barat terdiri dari dua bagian. Bagian terbesar berada di pulau Nias dan sebagian kecil terletak di pulau-pulau sebelah barat pulau Nias. Di Kabupaten Nias Barat terdapat 10 buah pulau kecil yang terdiri dari 5 pulau yang didiami penduduk dan 5 pulau tanpa penghuni. Kesepuluh pulau kecil tersebut berada di wilayah kecamatan Sirombu.

Badan BKD merupakan bagian dari suatu tatanan pemerintahan yang memegang peranan di dalam Sistem Pemerintahan di Indonesia, khususnya di Kabupaten Nias Barat. BKD berperan sebagai fasilitator serta sebagai dinamisator. Pemerintah bertindak mewakili kepentingan seluruh masyarakat, sehingga dalam menjalankan peranan tersebut, Pemerintah Daerah Kabupaten Kepulauan Nias Barat berkewajiban untuk meningkatkan manajemen pemerintahan yang lebih efisien, efektif, bersih, akuntabel serta berorientasi pada hasil.

Penelitian pengaruh Mutasi Pegawai terhadap Motivasi Kerja Aparatur Sipil Negara di Kantor BKD Kabupaten Nias Barat selama bulan juli 2017 mendepenelitiankan berbagai temuan dilapangan berdasarkan sebaran kuesioner. Pada bagian ini peneliti akan memaparkan identitas 32 responden untuk menghantar pada hasil dan pembahasan dalam penelitian pada bagian selanjutnya. Bagian ini secara khusus mendepenelitiankan frekuensi alamat responden, usia, jenis kelamin, jabatan, pangkat/golongan, pendidikan terakhir dan lama kerja responden.

Tabel 1. Distribusi Responden Berdasakan Usia

\begin{tabular}{|c|l|c|c|}
\hline No & \multicolumn{1}{|c|}{ Usia } & Frekuensi & Persentasi \\
\hline 1 & $17-25$ Tahun & 3 & 10,7 \\
\hline 2 & $26-35$ Tahun & 8 & 28,6 \\
\hline 3 & $36-45$ Tahun & 4 & 14,3 \\
\hline 4 & $46-55$ Tahun & 9 & 32,1 \\
\hline 5 & $56-65$ Tahun & 8 & 28,6 \\
\hline \multicolumn{2}{|l|}{ Total } & 32 & 100,0 \\
\hline
\end{tabular}

Sumber : Kuesioner Penelitian, 2017

Berdasarkan sebaran data kuesioner kepada ASN di BKD Kabupaten Nias Barat dengan jumlah 32 respoenden ditemukan bahwa responden yang berusia 4655 mencapai 32,1 persen dan menyusul responden yang berumur 26-35 dan 56-65 Tahun mencapai $28,6 \%$, sedangkan usia responden yang paling rendah berusia 17-25 hanya mencapai $10,7 \%$ dari total responden. 
Tabel 2. Distribusi Responden Berdasakan Jenis kelamin

\begin{tabular}{|c|l|c|c|}
\hline No & \multicolumn{1}{|c|}{ Jenis kelamin } & Frekuensi & Persen (\%) \\
\hline 1 & Laki-laki & 18 & 64,3 \\
\hline 2 & Perempuan & 14 & 43,75 \\
\hline & Total & 32 & 100,0 \\
\hline
\end{tabular}

Sumber: Kuesioner Penelitian, 2017

Berdasarkan tabel di atas dapat disimpulkan bahwa jumlah responden lakilaki $(64,3 \%)$ lebih banyak dari perempuan $(43,5 \%)$ dari total responden 32 orang. Ini cenderung berpengaruh pada jabatan yang dipercayakan kepada masingmasing pegawai ASN yang akan dianalisis dalam pembahasan berikut.

Tabel 3. Distribusi Responden Berdasakan Jabatan

\begin{tabular}{|c|l|c|c|}
\hline No & \multicolumn{1}{|c|}{ Jabatan } & Frekuensi & Persen (\%) \\
\hline 1 & $\begin{array}{l}\text { Pengatur Muda-Penata } \\
\text { Tingkat I }\end{array}$ & 4 & 14,3 \\
\hline 2 & $\begin{array}{l}\text { Penata Muda-Penata } \\
\text { Tingkat I }\end{array}$ & 19 & 67,9 \\
\hline 3 & Pembina-Pembina Utama & 9 & 28,12 \\
\hline & Total & 32 & 100,0 \\
\hline
\end{tabular}

Sumber: Kuesioner Penelitian, 2017

Berdasarkan tabel di atas dapat disimpulkan bahwa Jabatan di bagian Penata Muda-Penata Tingkat I menduduki posisi tertinggi yaitu 67,9\%, Pembina Utama 17,9\% dan yang paling rendah 14,3 adalah Penata Muda Tingkat I (Pertama).

Tabel 4. Distribusi Responden Berdasarkan

Golongan/jabatan

\begin{tabular}{|c|l|c|c|}
\hline No & Golongan & Frekuensi & Persen (\%) \\
\hline 1 & II/a-II/d & 8 & 25 \\
\hline 2 & III/a-III/d & 19 & 67,9 \\
\hline 3 & IV/a-IV/e & 8 & 25 \\
\hline & Total & 32 & 100,0 \\
\hline
\end{tabular}

Sumber: Kuesioner Penelitian, 2017

Berdasarkan tabel 4 ditemukan dari distribusi reponden berdasarkan golongan/jabatan didominasi oleh golongan III/a-III/d mencapai 67,9\%, sedangkan golongan terkecil didominasi oleh golongan II/a-II/d dari 32 responden pegawai BKD Nias Barat.

Tabel 5. Distribusi Frekuensi Pendidikan Responden

\begin{tabular}{|c|l|c|c|}
\hline No & \multicolumn{1}{|c|}{ Pendidikan } & Frekuensi & Persen (\%) \\
\hline 1 & SLTA & 1 & 3,6 \\
\hline 2 & D1/D2/D3 & 13 & 40,62 \\
\hline 3 & Sarjana (S1) & 20 & 71,4 \\
\hline 4 & Pasca Sarjana (S2) & 2 & 7,1 \\
\hline
\end{tabular}


Tabel 5. Distribusi Frekuensi Pendidikan Responden

\begin{tabular}{|c|l|c|c|}
\hline No & Pendidikan & Frekuensi & Persen (\%) \\
\hline 1 & SLTA & 1 & 3,6 \\
\hline 2 & D1/D2/D3 & 13 & 40,62 \\
\hline 3 & Sarjana (S1) & 20 & 71,4 \\
\hline 4 & Pasca Sarjana (S2) & 2 & 7,1 \\
\hline & Total & 32 & 100,0 \\
\hline
\end{tabular}

Sumber: Kuesioner Penelitian, 2017

Berdasarkan ditribusi frekuensi pendidikan responden ditemukan dari tingkat pendidikan mulai SLTA, D1/D2/D3, Sarjana, Pasca Sarjana. Tingkat Pendidikan reponden paling tinggi adalah Sarjana mencapai $71,4 \%$, sedangkan pendidikan SLTA hanya 3,6\%.

Tabel 6. Distribusi Responden Berdasakan Lama kerja

\begin{tabular}{|c|l|c|c|}
\hline No & & Frekuensi & Persen $(\%)$ \\
\hline 1 & $1-10$ Tahun & 17 & 60,7 \\
\hline 2 & $11-20$ Tahun & 7 & 21,87 \\
\hline 3 & $21-30$ Tahun & 10 & 31,25 \\
\hline 4 & $31-40$ Tahun & 2 & 7,1 \\
\hline & Total & 32 & 100,0 \\
\hline
\end{tabular}

Sumber: Kuesioner Penelitian, 2017

Berdasakan tabel di atas, ditemukan data responden dengan lama kerja paling lama adalah 1-10 responden $60,7 \%$, menyusul 21-30 lama kerja 31,25\% dan lama kerja terendah adalah 31-40 tahun adalah 7,1\%.

\section{HASIL PENELITIAN}

Uji validitas ini dilakukan untuk mengetahui kecocokan angket untuk menjaring data yang dibutuhkan. Jika terdapat koefisien korelasi dan taraf signifikan sebesar 10\% (0.1) Dengan taraf tersebut maka instrument dinyatakan valid. Nilai $\mathrm{r}$ hitung diambil dari output SPSS Cronbach Alpha. sehingga menghasilkan nilai $r$ tabel sebesar 0.3061

(dilihat dari tabel statistik $\mathrm{r}$ tabel berdasarkan sampel yang digunakan).

Dasar pengambilan keputusan untuk menguji validitas kuesioner adalah :

1. Jika $r_{\text {hitung }}>r_{\text {tabel }}$, maka variabel tersebut dikatakan valid.

2. Jika $r_{\text {hitung }}<r_{\text {tabel }}$ maka variabel tersebut dikatakan tidak valid.

Pada pengujian ini akan dihasilkan keakuratan dari angket tentang Variabel $\mathrm{X}$. Hasil dari uji validitas instrument untuk Variabel $\mathrm{X}$.dapat disajikan dalam tabel dibawah ini :

Tabel 7. Hasil uji Validitas kuesioner Mutasi Pegawai (X)

\begin{tabular}{|c|c|c|c|}
\hline $\mathbf{X}$ & $\mathbf{r}_{\text {hitung }}$ & $\mathbf{r}_{\text {tabel }}$ & Keterangan \\
\hline Item Pertanyaan No.1 & 0,687 & 0,289 & Valid \\
\hline Item Pertanyaan No.2 & 0,828 & 0,289 & Valid \\
\hline Item Pertanyaan No.3 & 0,921 & 0,289 & Valid \\
\hline Item Pertanyaan No.4 & 0,822 & 0,289 & Valid \\
\hline Item Pertanyaan No.5 & 0,850 & 0,289 & Valid \\
\hline Item Pertanyaan No.6 & 0,687 & 0,289 & Valid \\
\hline Item Pertanyaan No.7 & 0,828 & 0,289 & Valid \\
\hline
\end{tabular}




\begin{tabular}{|c|c|c|c|}
\hline Item Pertanyaan No.8 & 0,921 & 0,289 & Valid \\
\hline Item Pertanyaan No.9 & 0,822 & 0,289 & Valid \\
\hline Item Pertanyaan No.10 & 0,850 & 0,289 & Valid \\
\hline Item Pertanyaan No.11 & 0,687 & 0,289 & Valid \\
\hline Item Pertanyaan No.12 & 0,828 & 0,289 & Valid \\
\hline Item Pertanyaan No.13 & 0,921 & 0,289 & Valid \\
\hline
\end{tabular}

Sumber: Hasil Perhitungan SPSS, 2017

Dari Tabel diatas dapat dilihat bahwa nilai dari $\mathrm{r}$ hitung keseluruhan indikator $\mathrm{X}$ yang diuji bernilai positif dan lebih besar dari nilai $\mathrm{r}$ tabel yang besarnya adalah 0,289 oleh karena Nilai $r$ hitung semua indikator yang diuji lebih besar dari pada nilai $\mathrm{r}$ tabel, maka kesimpulan indikator $\mathrm{X}$ tersebut dinyatakan valid.

Tabel 8. Hasil Uji Validitas Motivasi Pegawai (Y)

\begin{tabular}{|c|c|c|c|}
\hline $\mathbf{Y}$ & $\mathbf{r}_{\text {hitung }}$ & $\mathbf{r}_{\text {tabel }}$ & Keterangan \\
\hline Item Pertanyaan No.1 & 0,782 & 0,289 & Valid \\
\hline Item Pertanyaan No.2 & 0,840 & 0,289 & Valid \\
\hline Item Pertanyaan No.3 & 0,798 & 0,289 & Valid \\
\hline Item Pertanyaan No.4 & 0,841 & 0,289 & Valid \\
\hline Item Pertanyaan No.5 & 0,922 & 0,289 & Valid \\
\hline Item Pertanyaan No.6 & 0,782 & 0,289 & Valid \\
\hline Item Pertanyaan No.7 & 0,840 & 0,289 & Valid \\
\hline Item Pertanyaan No.8 & 0,798 & 0,289 & Valid \\
\hline Item Pertanyaan No.9 & 0,841 & 0,289 & Valid \\
\hline Item Pertanyaan No.10 & 0,922 & 0,289 & Valid \\
\hline Item Pertanyaan No.11 & 0,922 & 0,289 & Valid \\
\hline
\end{tabular}

Sumber : Hasil Pengolahan Data Kuesioner SPSS 22, 2017

Dari tabel diatas dapat dilihat bahwa nilai dari $\mathrm{r}$ hitung keseluruhan indikator $\mathrm{Y}$ yang diuji bernilai positif dan lebih besar dari nilai $\mathrm{r}$ tabel yang besarnya adalah 0, 289 oleh karena Nilai $r$ hitung semua indikator yang diuji lebih besar daripada nilai $r$ tabel, dapat diambil kesimpulan bahwa semua butir indikator Y tersebut dinyatakan valid.

Uji reliabilitas merupakan uji kehandalan yang bertujuan untuk mengetahui seberapa jauh sebuah alat ukur dapat diandalkan atau dipercaya. Dimana secara umum yang dianggap reliabel apabila nilai cronbach alph $>0.6$

(ketentuan dari metode cronbach alpha) Hasil lengkap uji reliabilitas dapat dilihat pada tabel berikut ini :

Tabel 9. Hasil Uji Reliabilitas Kuesioner Variabel X

\begin{tabular}{|c|c|c|c|}
\hline Variabel & Cronbach's Alpha & Syarat & Keterangan \\
\hline$(\mathrm{X})$ & 0,783 & 0,6 & Reliabel \\
\hline
\end{tabular}

Sumber: Hasil Perhitungan SPSS, 2017

Dari tabel diatas dapat diketahui bahwa nilai Cronbach's Alpha dari seluruh variabel yang diajukan nilainya sudah diatas 0.60 Maka dapat disimpulkan bahwa seluruh variabel dalam penelitian ini lolos dalam uji reliabilitas dan dinyatakan reliabel. 
Tabel 10. Hasil Uji Reliabilitas Kuesioner Variabel Y

\begin{tabular}{|l|l|l|l|}
\hline Variabel & Cronbach's Alpha & Syarat & Keterangan \\
\hline$(\mathrm{Y})$ & 0,776 & 0,6 & Reliabel \\
\hline
\end{tabular}

Sumber : Hasil Pengolahan Data Kuesioner SPSS 22, 2017

Dari tabel diatas dapat diketahui bahwa nilai Cronbach's Alpha dari seluruh variabel yang diajukan nilainya sudah di atas 0,60. Maka dapat disimpulkan bahwa seluruh variabel dalam penelitian ini lolos dalam uji reliabilitas dan dinyatakan reliabel. Uji t pada dasarnya dilakukan untuk menguji apakah variabel Mutasi Pegawai (X) secara parsial atau individu mempunyai pengaruh positif dan signifikan terhadap Motivasi Kerja (Y). Nilai $t_{\text {hitung dapat diperoleh dengan }}$ menggunakan alat bantu program statistik seperti pada Tabel dibawah.

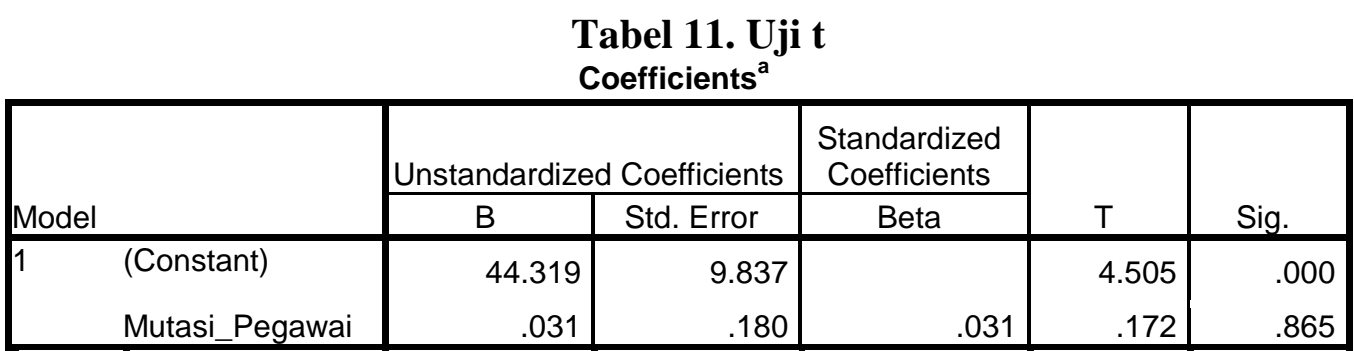

a. Dependent Variable: Motivasi_Kerja

Sumber : Hasil Pengolahan data SPSS 22

Berdasarkan Tabel bahwa variabel $\mathrm{X}$ memiliki nilai $\mathrm{t}_{\text {hitung }}$ sebesar 4,505 dengan tingkat signifikasi 0,000 yang lebih kecil daripada alpha $\alpha=0,1$ dimana $t_{\text {hitung }} 4,505$ lebih besar dari $t_{\text {tabel }}$ (signifikansi $0,1 / 2=0,05$ dengan derajat kebebasan $\mathrm{df}=\mathrm{n}-2$ atau 32-1 $=31$, hasil yang diperoleh untuk $\mathrm{t}$ tabel sebesar 1,705, maka $t_{\text {hitung }}(4,505) \geq t_{\text {tabel }}$ (1.696), sehingga Ho ditolak. Berarti Mutasi pegawai $(\mathrm{X})$ berpengaruh secara positif dan signifikan terhadap terhadap Motivasi kerja $(\mathrm{Y})$.

Analisis Regresi Linear Sederhana digunakan untuk mengetahui hubungan atau pengaruh antara satu variabel bebas (X) dengan satu variabel tergantung (Y) yang ditampilkan dalam bentuk persamaan regresi. Analisis ini bertujuan untuk memprediksikan nilai dari variabel tergantung apabila nilai variabel bebas mengalami kenaikan atau penurunan dan untuk mengetahui arah hubungan.

Tabel 12. Hasil Regresi Linear Sederhana Coefficients $^{\mathrm{a}}$

\begin{tabular}{|c|c|c|c|c|c|}
\hline \multirow[t]{2}{*}{ Model } & \multicolumn{2}{|c|}{ Unstandardized Coefficients } & \multirow{2}{*}{\begin{tabular}{|l}
$\begin{array}{l}\text { Standardized } \\
\text { Coefficients }\end{array}$ \\
Beta
\end{tabular}} & \multirow[t]{2}{*}{ T } & \multirow[t]{2}{*}{ Sig. } \\
\hline & $B$ & Std. Error & & & \\
\hline (Constant) & 2,344 & 5,345 & &, 569 & ,945 \\
\hline$X$ & 863 & 094 & 875 & 9,207 &, 000 \\
\hline
\end{tabular}

Sumber : Hasil Pengolahan Data Kuesioner SPSS 22, 2017

Berdasarkan hasil pengolahan data pada tabel diatas pada kolom Unstandardized Coefficients nilai B diperoleh model persamaan regresi linear sederhana sebagai berikut:

$$
\mathbf{Y}=\mathbf{a}+\mathbf{b X}+\mathbf{e}
$$




$$
Y=2,344+0,86 X+e
$$

Dari persamaan regresi diatas dapat dijelaskan sebagai berikut:

a. Konstansta (a) = 2,344 menunjukkan jika tidak ada variabel Mutasi pegawai (X) maka Motivasi kerja 2,344

b. Koefisien regresi variabel Mutasi Pegawai $(X)=0.863$ menunjukkan bahwa setiap kenaikan 1\% variabel Mutasi kerja akan mendorong Motivasi kerja sebesar 0.863. artinya adalah setiap kenaikan 1\% Mutasi Pegawai akan mendorong meningkatnya Motivasi Kerja sebesar 0.863

Pengujian koefisien determinasi atau $\mathrm{R}^{2}$ digunakan untuk mengetahui seberapa besar variasi variabel dependen yaitu Motivasi kerja dijelaskan oleh variasi variabel independen yaitu. Mutasi Pegawai, Hasil perhitungan koefisien determinasi atau R.square $\left(\mathrm{R}^{2}\right)$ dapat dilihat pada tabel berikut ini.

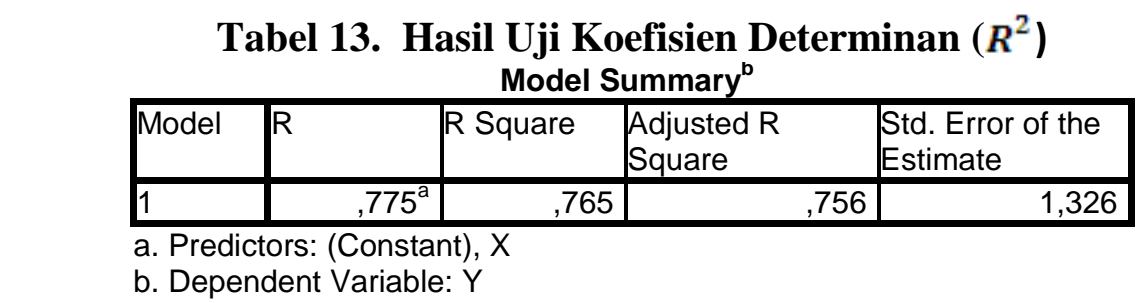

Sumber : Hasil Pengolahan Data Kuesioner SPSS 22, 2017

Berdasarkan Tabel 13 di atas hasil analisa regresi secara keseluruhan menunjukkan nilai koefisien korelasi (R) sebesar 0,765 yang berarti korelasi atau hubungan antara variabel Mutasi pegawai terhadap Motivasi Kerja sebesar 0,775. Artinya memiliki hubungan yang Kuat dan bersifat positif. Sedangkan nilai $R$ square atau nilai koefisien determinasi sebesar 0,765 yang berarti bahwa presentase pengaruh variabel independen $(\mathrm{X})$ terhadap variabel dependen $(\mathrm{Y})$ sebesar 0,765 atau variabel independen hanya mampu menjelaskan $76.5 \%$ terhadap variabel dependen (Y) sedangkan selebihnya $23.5 \%$ (100\%-76.5\%) dipengaruhi oleh faktor-faktor lain.

\section{PEMBAHASAN}

Dari hasil pengujian hipotesis atau uji koefisien regresi linear sederhana di atas dapat di lihat pada tabel 4.38 yaitu :

a. Konstansta (a) = 2,344 menunjukkan jika variabel Mutasi Pegawai (X) bernilai nol maka Motivasi Kerja 2,344

b. Koefisien regresi variabel Mutasi kerja $(X)=0.863$ menunjukkan bahwa setiap kenaikan 1\% variabel Mutasi kerja akan mendorong Motivasi kerja sebesar 0.863. artinya adalah setiap kenaikan 1\% Mutasi Pegawai akan mendorong meningkatnya Motivasi Kerja sebesar 0.863

Hasil olah data statistik tersebut dapat dijelaskan bahwa pengaruh Mutasi Pegawai merupakan salah satu faktor penting yang menunjang tercapainya Motivasi Kerja di Badan Kepegawaian Daerah (BKD) tersebut. Berdasarkan Tabel 4.39 di atas hasil analisa regresi secara keseluruhan menunjukkan nilai koefisien korelasi (R) sebesar 0,765 yang berarti korelasi atau hubungan antara variabel Mutasi Pegawai terhadap Motivasi Kerja sebesar 0,775. Artinya memiliki hubungan yang Kuat dan bersifat positif. Sedangkan nilai $R$-square atau nilai koefisien determinasi sebesar 0,765 yang berarti bahwa presentase pengaruh 
variabel independen (X) terhadap variabel dependen (Y) sebesar 0,765 atau variabel independen hanya mampu menjelaskan $76.5 \%$ terhadap variabel dependen (Y) sedangkan selebihnya 23.5\% (100\%-76.5\%) dipengaruhi oleh faktor-faktor lain.

Faktor-faktor yang mempengaruhi lemahnya motivasi kerja pegawai ASN yaitu :

1. Hubungan yang harmonis antara pimpinan dengan bawahan

Ketidak harmonisan tersebut merupakan gambaran adanya sesuatu yang tidak beres dalam organisasi, yaitu adanya rasa ketidak puasan pegawai terhadap perlakuan buruk pimpinan organisasi. Bila organisasi tetep konsisten memperlakukan pegawai dengan baik, memberikan hak-hak mereka dengan baik, tentu tidak timbul keresahan demikian yang bisa menimbulkan kerugian bagi kedua belah pihak. Oleh karena itu, organisasi harus dapat menciptakan kepuasan kerja bagi pegawainya dengan tetap memberikan segala hak-hak mereka sesuai dengan peraturan yang berlaku. Begitu pula, dengan ketidakpuasan tersebut akan menimbulkan stress atau tekanan batin dan goncangan mental yang besar bagi para pegawai.

2. Kepuasan para karyawannya terhadap tugas dan pekerjaannya.

Kepuasan kerja merupakan kondisi lahir dan batin seseorang dalam melakukan pekerjaan. Walaupun kadar kemampuan kerja tersebut berbedabeda untuk setiap orang, tetapi pada dasarnya ada hal-hal umum yang harus dipenuhi untuk terdapatnya kepuasan kerja bagi para pegawai. Pada umumnya, seorang pegawai akan dapat merasa puas apabila dalam pekerjaannnya terdapat kesempatan memperoleh umpan balik tentang hasil pekerjaan yang telah dilakukan.

\section{KESIMPULAN DAN SARAN}

"PENGARUH MUTASI PEGAWAI TERHADAP MOTIVASI KERJA APARATUR SIPIL NEGARA (Studi Kasus di Kantor Badan Kepegawaian Daerah (BKD) Kabupaten Nias Barat. Sesuai dengan tujuan penelitian dalam penyusunan penelitian ini, yaitu : (i) Mengevaluasi efek mutasi jabatan terhadap motivasi kerja pada pegawai BKD, dan (ii) Menganalisis besarnya efek mutasi jabatan terhadap motivasi kerja terhadap pegawai di BKD kabupaten Nias Barat. Hasil dari penelitian dan pembahasan analisis adalah sebagai berikut:

1. Hasil pengujian dengan menggunakan regresi linear sederhana dimana didapat persamaan regresi sebagai berikut $\mathrm{Y}=2,344+0,86 \mathrm{X}+\mathrm{e}$ yang menunjukkan adanya pengaruh Mutasi Pegawai terhadap Motivasi kerja.

2. Dengan menggunakan analisis regresi linear sederhana dapat diketahui bahwa pengaruh Variabel $\mathrm{X}$ terhadap $\mathrm{Y}$ pegawai Kantor Badan Kepegawaian Daerah Kabupaten Nias Barat sebesar 76,5\%. Sedangkan sisanya sebesar $23,5 \%$ dipengaruhi atau dijelaskan oleh faktor lain yang tidak dimasukkan dalam metode penelitian ini.

3. Adanya efek positif dari Mutasi Pegawai terhadap motivasi kerja pada pegawai di Kantor Badan Kepegawaian Daerah. Di mana efek positif ini terjadi karena adanya keterkaitan hubungan yang kuat 
antara Mutasi Pegawai terhadap Motivasi Kerja pada pegawai , sehingga memberikan pengaruh yang positif.

Berdasarkan kesimpulan tersebut di atas, peneliti memiliki saran kepada BKD Nias Barat yaitu :

1. Dengan meneruskan program Mutasi Pegawai secara berkala tersebut. Penempatan dalam jabatan serta mutasi bagi Aparatur Sipil Negara di lingkungan Kantor BKD Kabupaten Nias Barat menjadi suatu karir yang hidup dan berkelanjutan, hendaknya benar-benar berpedoman pada persyaratan-persyaratan jabatan dan peraturan perundang-undangan yang berlaku. Sehingga Motivasi Kerja terus tumbuh dan berkembang bagi ASN

2. Pegawai BKD merupakan ASN Nias Barat yang bergerak di bidang kepegawaian sesuai tugas pokok dan fungsinya (Tupoksi) yaitu membantu terlaksananya sistem pemerintahan yang professional dan bertanggungjawab. Berdasarkan hasil penelitian, disarankan agar Badan Kepegawaian Daerah (BKD) untuk lebih meningkatkan motivasi kerja kepada pegawai, sehingga tercapainya tujuan organisasi yang efektif dan efisien.

\section{DAFTAR PUSTAKA}

Arikunto, Suharsimin. Prosedur Penelitian suatu Pendekatan Praktik. Jakarta: PT. Asdi Mahasatya, 2013.

Hasibuan, Malayu S.P. Manajemen Sumber Daya Manusia. Jakarta: PT. Bumi Aksara, 2016.

Liang Gie (Sadili Samsudin). Manajemen Sumber Daya Manusia. Bandung: CV Pustaka Setia, 2005.

Martono, Nanang. Metode Penelitian Sosial: Konsep-Konsep Kunci. Jakarta:

PT. RajaGrafindo Persada, 2015.

Musanef. Manajemen Kepegawaian di Indonesia. Jakarta: PT. Gunung Agung, 2014.

Nitisemo, Alex S. Manajemen Personalia. Jakarta: Balai Aksara, 2015.

Paul Pigors dan Charles Mayers (Malayu S.P. Hasibuan), Manajemen Sumber Daya Manusia. Jakarta: PT. Bumi Aksara, 2016.

Samsudin, Sadili. Manajemen Sumber Daya Manusia. Bandung: CV Pustaka Setia, 2010.

Siagian, Sondang P. Manajamen Sumber Daya Manusia. Jakarta: PT. Bumi Aksara, 2013.

Sastrohadiwiryo, Siswanto. Manajamen Tenaga Kerja Indonesia. Jakarta:

PT. Bumi Aksara, 2003.

Sugiyono. Metode Penelitian Kuantitatif, Kualitatif, dan Kombinasi. Bandung: Alfabeta, 2014.

Silalahi, Uber. Metodologi Penelitian Sosial Kuantitatif. Bandung: PT. Refika Aditama. 2017.

Wursanto. Manajemen Kepegawaian. Jilid II. Jakarta: Kanisius, 2007.

Undang-Undang Republik Indonesia Nomor 5 Tahun 2014 Tentang Aparatur Sipil Negara Peraturan Pemerintah Republik Indonesia Nomor 9 Tahun 
2003 tentang Wewenang pengangkatan, pemindahan, dan Pemberhentian Pegawai Negeri Sipil 